\title{
Seaports of Primorsky Krai in the Transport System of the Region in the Conditions of the Free Port of Vladivostok
}

\author{
Andrei Ivanovich Fisenko*, Elena Vital'evna Khamaza, Elena Aleksandrovna Khamaza, llya \\ Olegovich Khamaza and Ekaterina Sergeevna Megei \\ FSFEl of HPE Admiral Nevelskoy Maritime State University, Vladivostok, Russia; \\ andreifisenko1957@mail.ru
}

\begin{abstract}
The article considers the tendencies of socioeconomic development of Primorsky Krai in the modern conditions of development of the national economy of Russia and the tasks of formation of the transport and logistics infrastructure in the region to enable it to secure and implement its territorial transport, logistics and transit functions. A key role in this development is played by the seaports of the southern zone of the Far East and, in particular, of Primorsky Krai. It focuses on the tasks, as well as various aspects of the formation and direction of implementation of the promising socio-economic and political project of Russia in the Far East-the establishment of the Free Port of Vladivostok. This project focuses on the issues of providing Russian seaports in Primorye with a cargo base, as well as economic, social, organizational, infrastructural, political, legal and other aspects of operation of the Free Port of Vladivostok. Cargoes from the northeast provinces of China, as well as the implementation of major Russian projects, in particular, the project of establishment of "priority development territories" in Primorsky Krai play an important role in providing a cargo base and ensuring effective performance of seaports in Primorye.
\end{abstract}

Keywords: Cargo Base, Priority Development Territories, Primorsky Krai Seaports, The Free Port of Vladivostok, Transport and Logistics Hub

\section{Introduction}

Obviously, the determining vector of economic development of the Far East and Primorsky Krai, in particular, in the coming years will be the establishment and operation of the Free Port of Vladivostok (FPV). As the Federal Law "On the Free Port of Vladivostok" signed by Russian President V.V. Putin on July 13, 2015 reads, the Free Port of Vladivostok is established for seventy years. It reserves the possibility to extend this period, as well as to early terminate the measures of state support for entrepreneurial activities on its territory ${ }^{1}$.

Financial support for the establishment and modernization of facilities of the transport, industrial and social infrastructure in the territory of the Free Port of Vladivostok will be provided at the expense of extra- budgetary sources involving the mechanisms of publicprivate partnerships, as well as in the manner prescribed by the budget legislation of the Russian Federation.

The Free Port of Vladivostok will be managed by the Supervisory Board, a special federal body of executive authority in the Far Eastern Federal District, the functions of which include coordination of government programs and implementation of federal target programs (in the law referred to as the "authorized federal body"), as well as by a management company, defined by the Government of the Russian Federation in accordance with Federal Law \#473-FZ dated 29.12.2014 "On the Territories of Priority Socio-Economic Development in the Russian Federation"', or its subsidiary.

In the free port, a special legal regime of business and investment activities will be in effect, and the best business

${ }^{*}$ Author for correspondence 
environment will be created as compared to similar areas in the Asia-Pacific Region (APR). The effect of the bill extends to 15 municipalities of Primorye. Also, the law provides additional mechanisms to support residents and forms the standards that allow establishing a free port zone (Porto Franco) in the Free Port of Vladivostok.

According to the developers, the adoption and implementation of the bill on the establishment of the Free Port will result in the growth of the Gross Regional Product (GRP) of Primorsky Krai by 2021 to 1.1 trillion rubles (or by 1.7 times compared to 2015), and by 20251.4 trillion rubles (or by 2.2 times compared to 2015). Accordingly, the increment of the GRP of Primorsky Krai by 2021 will amount to 470.1 billion rubles and by 2025to 766.2 billion rubles. In this case, the number of jobs created by 2021 will reach 84.7 thousand, and by 2025108 thousand $^{3}$.

How, in what direction and by what means will the Free Port of Vladivostok be developing? What needs to be done to make this project become a success? What problems, despite the fact that the law has been adopted, are still to be resolved? These and other questions are not an exhaustive list of questions that are arising today in the practice of solving the problems of the Free Port of Vladivostok establishment. We are about to consider some of them that, in our opinion, are directly related to the so-called "maritime component" of the Free Port of Vladivostok.

However, before we consider them, let us see what factors will determine the development of the Russian Far East (including Primorsky Krai) for the next 10-15 years. In our view, the most significant trends that will have a decisive influence on the socio-economic development of the Far East and Primorsky Krai in the nearest future, apparently, will be the following:

- A slowdown of the Russian Federation's economy development and a possible creeping recession in the medium term-in 2015-2017. In line with the forming international economic and domestic economic situation, the growth rate of the gross domestic product of the Russian Federation, according to our estimates, in the period up to 2018-2020 will be less than $0.5-1.5 \%$ per year, and if the situation changes (termination of sanctions, a growth of the world industrial oil consumption and revival of the situation on the global and regional commodity markets), it will be maintained at the level of 1.5-3\% per year (for the next 3-5 years);

- Implementation of major investment projects, in- cluding those in Siberia and the Far East, particularly, the implementation of the Sakhalin projects for hydrocarbons extraction, as well as major projects in the transportation of raw materials (primarily, in the Arctic, along the Northern Sea Route);

- Consolidation of the current economic specialization of the Russian Federation's regions, a shift and transformation of the country's main investment package towards the eastern regions-Siberia and the Far East;

- Implementation of government projects aimed at improving the investment attractiveness of the Far Eastern regions of the Russian Federation (establishment of special economic zones, including the free port project in Primorsky Krai, establishment of technology parks and PDTs ("Priority Development Territories"), gambling zones, implementation of transport and logistic development projects in the region, etc.). According to experts, only the development and modernization of the transport infrastructure will reduce the cost of transportation in the Far East by about $40 \%$;

- Intensive development of the versatile and multi-faceted cooperation with China in all areas and spheres of public and private cooperation (business, culture, "people's diplomacy", etc.), as well as with the Republic of Korea, North Korea and the BRICS countries.

What does this mean, particularly, for Primorsky Krai, for example, in the sphere of transport and logistic support of the regional economic development? To our opinion, first of all it means the following:

- Rapid economic development of the base material sector, the processing industry (primarily, processing of hydrocarbons, minerals and seafood), and the transport and logistics sector (primarily the construction of specialized terminals and establishment of sea and air hubs);

- The possibility of implementing a number of major national projects, primarily in the sector of customs, transportation and processing of base materials, as well as increasing the added value of products of the processing industries in connection with the strengthening of the eastern direction of supplies of Russian base materials for Primorsky Krai (oil and product pipelines, international transport corridors, construction of FEPCO and new berths at seaports, establishment of the free port zone in Vladivostok, transformation of the Vostochny port into a regional transshipment center, etc.);

- The opportunity to use its geographical, geo-economic and geopolitical position to implement the policy of economic integration of the Russian Federation in 
the Asia-Pacific Region, and, on this basis, to change the quality of the economic growth of the region by its incorporation into the transport-logistics and economic system of relations with the Asia-Pacific countries through the establishment of a state-of-the-art international Transport and Logistics Hub (TLH). It is particularly important in this context to fulfill the region's transit capacity and implement projects in the field of trade and tourism services development (development of the transit from Northeast China and the international transit through the territory of the Russian Federation in the southern zone of Primorye; maritime, extreme and ecological tourism and cruising). The main objective of the transport and logistics cluster that is being formed in such a way in the region is to integrate it the transport and logistics system of the Asia-Pacific Region and bring the transport and logistics system of Primorsky Krai in line with the standards of the Asia-Pacific Region so as to ensure high and stable functional income.

By implementing these prerequisites, Primorsky Krai will be able to consolidate its territorial transport-logistics and transit functions. This will ensure:

- Firstly, the dynamic development of the basic transport sector-the implementation of projects for the construction of sea, road and rail terminals, specializing in transshipment of coal, grain, oil and refined petroleum products, container handling; the formation and development of the free port zone based on a number of ports of the southern part of Primorsky Krai (primarily Nakhodka, Vladivostok, Zarubino, Posyet and others), specializing in customs clearance, handling and processing of main export commodities of the Russian Federation (coal, grain, metal, wood, etc.) and in transit of goods from the Northeast China and Asia-Pacific countries;

- Secondly, the rapid development of the modern transport-logistics (primarily road, rail, air and marine) and trade infrastructure, which provides the growth of budget revenues of Primorsky Krai from commodity flows and services passing its territory and created here, including by establishing cross-border trade and industrial hubs, checkpoints, special customs and production-recreation (including gambling) zones.

The tasks that the Government sets to the transport and logistics hub of the Far East and Primorsky Krai cannot be solved without full and effective development of sea ports and their transport infrastructure. Therefore, one of the most important tasks of the TLHs of the region is now to develop the ports in the south of Primorsky Krai and improve their competitiveness to the level of the best seaports in the Asia-Pacific Region and even higher, and above all, to increase the capacity of the ports of Primorsky Krai, in the first place, by encouraging technological modernization of port facilities in order to increase their performance and the capacity of the major transport hubs ${ }^{4-7}$.

To solve this task, it is necessary to:

Establish an industrial port zone and echeloned port based on the existing ports (Vostochny, Nakhodka, Zarubino etc.), including the construction of a modern terminal complex, storage facilities, a second railway track from the Nakhodka-Vostochnaya railway station to the Khmylovsky shunting loop, as well as a bypass road to the city of Nakhodka. The prospective cargoes of this port will be containerized cargo, coal, petrochemical products, grain, timber industry products (mainly timber) and products of fish processing;

Provide more expressed specialization of the transport hubs: The universal port complex VostochnyNakhodka; the port in the Kozmino Bay-a specialized export port of regional importance (oil and oil products); the port in the Sukhodol Bay-mainly specializing in coal transshipment; the port in the Troitsa Bay-a regional port specializing in transshipment of coal, containers and other cargoes, including the transit ones coming from China; the Vladivostok transport hub, specializing in container and horizontal cargo handling, the port of Zarubino, specializing in container cargoes, grain, etc.;

Develop industrial zones and synchronize them with the enlargement of port facilities and the capacity of railways (especially specializing in oil refining and gas processing (including petrochemicals and petroleum gas chemicals), wood working, fish and seafood processing, production of shipbuilding and ship repair products, metal processing, high-tech products, etc.), and establish on this basis new territories (cities, settlements) of innovative and technological development and procurement of the FPV operation.

\section{The Current Status and Development Trends of Seaports in Primorsky Krai and their Cargo Base.}

For 2006-2014, the turnover of Russian seaports has increased by $148.1 \%$ and exceeded 623 million tons, and the turnover of the ports of the Far Eastern basin has 
increased by 2.4 times, reaching 162.5 million tons in $2014^{4}$. The growth rate of turnover of the Far Eastern ports was roughly twice as high-about $8.5 \%$ per year on the average (Table 1). This is due to the huge investments in the development of the ports' infrastructure, as well as to an increase in the turnover with the countries of Asia and America-China, Mongolia, Japan, Australia, the USA and others. In addition, there are international transport corridors-"Primorye-1" and "Primorye-2"-passing through a number of seaports. For example, the ports' turnover growth in 2014 was caused by an increase in shipment of coal to China. At the same time, the turnover of dry cargo amounted to 97 million tons $(+16.3 \%)$. In addition, the transshipment of liquid bulk cargo (mainly oil) has increased and reached 65.5 million tons (+6.7\%).

Port Vostochny holds the first place in terms of turnover growth, as it has increased transshipment in 2014 to 57.8 million tons $(+19.7 \%)$. This includes an increase in turnover at the Universal Handling Complex, which amounts to $40 \%$ (4.5 million tons). The Coal Complex processed 17.3 million tons of coal, which is by 19.1\% higher than in 2013 (Table 2).

Port Posyet holds the second place in terms of the growth of the cargo turnover, which has increased to 6.7 million tons $(+18.8 \%)$. This is due to the infrastructure modernization, in particular, construction of a new transshipment complex. While the expected 7 million tons of cargo turnover have not yet been reached, this goal will be achieved as soon as in 2015 .

As for the port of Vladivostok, despite the fact that it is not the first one in terms of the cargo turnover among the region's seaports ( 15.3 million tons $(+5.3 \%$ compared to 2013)), in the long run it is planned to use its facilities and create the FPV, a seaport with a preferential customs regime and a number of additional services. This will attract new investment to the region and make it one of the largest ports in the Asia-Pacific Region in the future. It is assumed that in this case the port's cargo turnover may grow by 1.4 times by $2020^{7}$.
Table 2. The growth of turnover of the largest seaports of the Far East in 2013-2014 (million tons)*

\begin{tabular}{lccc}
\hline $\begin{array}{l}\text { The largest seaports } \\
\text { of the Far East }\end{array}$ & 2013 & 2014 & $\begin{array}{c}\text { 2014 to } \\
\text { 2013, in \% }\end{array}$ \\
\hline Vostochny & 45.84 & 57.8 & 119.7 \\
Vanino & 23.48 & 26.2 & 110.4 \\
Nakhodka & 18.01 & 20.7 & 113.0 \\
Vladivostok & 14.49 & 15.3 & 105.3 \\
De-Kastri & 6.84 & 8.2 & 116.6 \\
Posyet & 5.31 & 6.7 & 118.8 \\
\hline * - compiled by the materials of:19. & &
\end{tabular}

However, an analysis of the cargo and container turnover of the largest seaports of northeast and southeast Asia indicates that Russian ports are still far behind those ports' performance (Table 3). As Table 3 shows, in 2013, for example, only the turnover of the Chinese seaport Ningbo-Zhoushan amounted to 809.8 million tons or $137.5 \%$ of the turnover of all Russian ports, and the container turnover of this port in the same year was more than 3.2 times higher than the turnover of all the seaports of Russia (5.35 million TEU). At the same time, the container turnover of the Russian ports in the Far Eastern basin in 2013 amounted to 1.56 million TEU, or nearly $30 \%$ of the total container turnover ${ }^{8}$. Even in the smallest seaport among the ports shown in Table 2-South Korean Busan-both the cargo and container turnover in 2013 were, respectively, by 1.8 and 11.3 (!) times higher than the turnover of the Far Eastern seaports ${ }^{8}$. In our opinion, we should not set the task to make Vladivostok second Busan and Hong Kong. Copies, even very good ones, as a rule, are rarely better than the original (this is why they are the originals!). However, making Vladivostok the first Vladivostok with its specialization, attractive conditions, finding "its" niche, "its" cargo and organizing the work here the way the customers need, in our opinion, is quite realistic and even necessary ${ }^{10-18}$.

Table 1. The growth of the freight turnover of Russian seaports in 2006-2014*

\begin{tabular}{lcccccccccc}
\hline Values & \multicolumn{1}{c}{ Years } & \multicolumn{1}{c}{ 2014 to } \\
\cline { 2 - 10 } & $\mathbf{2 0 0 6}$ & $\mathbf{2 0 0 7}$ & $\mathbf{2 0 0 8}$ & $\mathbf{2 0 0 9}$ & $\mathbf{2 0 1 0}$ & $\mathbf{2 0 1 1}$ & $\mathbf{2 0 1 2}$ & $\mathbf{2 0 1 3}$ & $\mathbf{2 0 1 4}$ & $\mathbf{2 0 0 6 , \%}$ \\
\hline Total turnover, million tons & 421 & 451 & 454.6 & 496.4 & 525.8 & 535.4 & 565.5 & 589 & 623.4 & 148.1 \\
Increase on the previous year, \% & 3.5 & 7.1 & 8.0 & 9.1 & 5.9 & 1.8 & 5.6 & 4.1 & 5.8 & - \\
Turnover of the Far Eastern ports, & 67.7 & 79.7 & 80.4 & 92.2 & 117.9 & 125.4 & 134.2 & 144.8 & 162.5 & 240.0 \\
million tons & & & & & & & & & \\
Increase on the previous year, \% & 4.6 & 17.7 & 0.8 & 14.7 & 27.9 & 6.4 & 7.0 & 7.9 & 12.2 & - \\
\hline
\end{tabular}

* - compiled by the materials of: 19 . 
Table 3. The cargo and container turnover of some of the largest seaports of northeast and southeast Asia in 2009-2013*

\begin{tabular}{|c|c|c|c|c|c|c|}
\hline Seaports & 2009 & 2010 & 2011 & 2012 & 2013 & 2013 to 2009 , in $\%$ \\
\hline 1. Ningbo-Zhoushan: & 520.1 & 570.0 & 691.0 & 744.0 & 809.8 & 155.7 \\
\hline $\begin{array}{l}\text { - Cargo turnover, million tons } \\
\text { - container turnover, million TEU }\end{array}$ & 12.73 & 13.56 & 14.72 & 16.83 & 17.33 & 136.1 \\
\hline 2. Shanghai: & 590.0 & 647.0 & 730.0 & 736.0 & 776.1 & 131.5 \\
\hline $\begin{array}{l}\text { - Cargo turnover, million tons } \\
\text { - container turnover, million TEU }\end{array}$ & 25.00 & 25.55 & 31.74 & 32.53 & 33.64 & 134.6 \\
\hline 3. Singapore: & 470.4 & 502.2 & 530.5 & 538.0 & 560.9 & 119.0 \\
\hline $\begin{array}{l}\text { - Cargo turnover, million tons } \\
\text { - container turnover, million TEU }\end{array}$ & 25.87 & 28.43 & 29.94 & 31.65 & 32.58 & 126.0 \\
\hline 4. Hong Kong: & 259.4 & 267.8 & 277.4 & 269.3 & 276.1 & 106.4 \\
\hline $\begin{array}{l}\text { - Cargo turnover, million tons } \\
\text { - container turnover, million TEU }\end{array}$ & 21.04 & 23.69 & 24.42 & 23.11 & 22.31 & 106.0 \\
\hline 5. Busan: & 222.4 & 208.1 & 269.9 & 270.9 & 260.0 & 116.9 \\
\hline $\begin{array}{l}\text { - Cargo turnover, million tons } \\
\text { - container turnover, million TEU }\end{array}$ & 11.98 & 13.94 & 16.18 & 17.04 & 17.69 & 147.7 \\
\hline
\end{tabular}

In this connection, there is the legitimate question: Is there a possibility for Russia to find its "own" cargo and increase the flow of goods (primarily, the transit one) through its ports in Primorsky Krai? What is the potential cargo base of the seaports included in the FPV, from where and whereto can cargo go and what cargo is it (we are not yet considering the possibility of processing the relevant volumes and interaction with the railway-it is a topic for another big conversation)?

Let us try to answer these questions.

In view of the adoption by the Russian Government of a number of decisions to accelerate the socio-economic development of Siberia and the Far East, including the prepared draft state program "Socio-economic development of the Far East and the Baikal Region until 2025 ", the traffic flows of the country are assumed to shift eastward in the near future. This will be also assisted by the strengthening of foreign economic links of Russia with rapidly developing countries of the Asia-Pacific Region. As a result, while in 2011 the share of the Far Eastern seaports in the total volume of transshipment of Russian goods accounted for $19.6 \%$, by 2030 it can rise to $22.7 \%$ (the expert scenario) - $23.8 \%$ (the baseline scenario). Overall, in the period from 2012 to 2030, the cargo base of the Russian Pacific ports will include mainly mineral and forest resources of East Siberia and the Far East, as well as with the functioning of the "East-West" transport corridor (mainly containers). Moreover, by
2030 the Far Eastern direction is about to face a growth in the demand for transshipment of cargoes to 234.1 million tons in the baseline scenario and to 292.4 million tons in the expert scenario ${ }^{19}$.

We find it important to note the fact that Russian ports in the Arctic, Baltic, Black Sea and Azov, Caspian and Far Eastern basins are the key elements of the transport system of Russia and entry points of the network of PanEuropean and Eurasian international transport corridors. However, currently despite the geographical advantages, Russia is between tenth and twentieth place by export of transport services among the countries rendering these services (less than $1 \%$ of trade turnover between the countries of Europe and Asia). It is only about $5 \%$ of the country's transit potential. But even those $5 \%$ of the total volume of transit traffic in the Euro-Asian communication can ensure the growth of annual income of domestic transport and related companies by 2-3 billion US dollars. It is necessary to take into account the fact that the volume of trade between Europe and Asia reaches about 600 billion US dollars a year. Of this amount, the Russian transport communications potentially cover $10-15 \%$, or about 60-90 billion US dollars. Therefore, for the Russian Federation, the fulfillment of even this small share of the transit capacity can give an additional impetus for the implementation of large-scale projects for modernization and development of the transport infrastructure, creation of additional jobs, as well as a significant multiplier effect 
in other sectors of the economy and social sphere. An additional gross national income gained by the fulfillment of the transit potential of the Russian Federation in the Eurasian direction, according to estimates, could reach 350 billion rubles by $2015^{20}$.

According to calculations of the Ministry of the Far East Development of the Russian Federation, the amount of investment from the federal budget to the region, which will be able to raise it and force its development, should be at least 5.7 trillion rubles (excluding the cost of reconstruction of the Trans-Siberian and Baikal-Amur Railways, which is estimated at 1.5-2 trillion rubles). It is assumed that each budget ruble must involve more than four extra-budgetary rubles of investments. According to the program of the Russian Far East development, due to these measures, the investment is expected to grow by 3.8 times; the index of growth of the gross regional product in 2012-2025-to reach 2.57, the region's share in the Russian economy-to grow from $8.5 \%$ to $10.2 \%$; the industrial production-to increase by 1.7 times; and the manufacturing production-to grow from the current $5.5 \%$ to $8.5 \%$. An increase in the number of population living here from 10.4 to 12.4 million people is also expected, in spite of the fact that, according to official figures, from 1989 to 2012 the number of people in the region declined by almost $21 \%$. However, the question remains somewhat unclear, where, how and when the government will find such large funds, because this amount is almost equal (together with the cost of the Trans-Siberian and Baikal-Amur railways reconstruction) to the sum of the total expenditure of the budgets of all regions, i.e. approximately 7.8 trillion rubles. To compare, the amount of transfers from the federal budget to the budgets of regions in 2012 equaled to 1.8 trillion rubles approximately ${ }^{3}$.

According to the Transport Ministry, the freight traffic of the Far Eastern destinations today has exceeded the values of the crisis period for all types of transport (especially, the sea and railway transport, which now account for over $90 \%$ of the freight traffic in the region) and has a stable upward trend. Thus, in particular, the "Strategy of Development of the Seaport Infrastructure in Russia until 2030" suggests by 2020 an increase in the demand for the liquid cargo transshipment to almost 70 million tons, which is almost by $25 \%$ higher than in 2011 , the bulk cargo transshipment-up to 90 million tons (the growth is about 100\%), and the general and container cargo transshipment, respectively, up to 17 and 19 million tons (the growth exceeds 125\%). The total cargo base of the Far East by 2020 is estimated at over 200 million tons, which is by about $60 \%$ more than in 2011 (125 million tons) $)^{19,21}$.

Given that the Russian Economic Development Ministry forecasts in the near future an economic growth at the expense of developing countries (especially China and India-these economies could reach by 2020 about a quarter, and by 2030 about a third of the global GDP), the volume of transshipment of Russian Pacific seaports may increase by $30 \%$ by 2020 and double by $2030^{19}$. It is obvious that the implementation of these plans requires improving the competitiveness of the seaports of the Far East and the sea shipping in all directions in the region and, above all, increasing the speed of loading and unloading, reducing the time that ships and rail cars stay in the port, improving the process ability of operations, the time of customs clearance, etc. Currently, these figures are at least two or even three times lower than the world average and are significantly behind those of the leading Asian ports-Shanghai, Singapore, Hong Kong, Dalian, Qingdao, Busan, Nagoya, Niigata and others. As an example, it is sufficient to give such exemplary figures: The average speed of a freight train moving across the Far East in the east-west direction is $24 \mathrm{kph}$, and in the westeast direction even less-only $8 \mathrm{kph}$.

The problem resides in the limited capacity of the Trans-Siberian Railway. Now it accounts for over $80 \%$ of the cargo turnover and around $40 \%$ of the domestic passenger turnover in the region. Every year, the TransSiberian Railway carries in some areas up to 95 million tons of various cargoes, and the Baikal-Amur Mainline (BAM) transports every year from 12 to 20 million tons of cargoes, the major part of which is coal, oil and oil products. Over $75 \%$ of the cargo turnover by rail is linked to the main ports in Khabarovsk Krai and Primorsky Krai. At the same time, the ports of the Far East, such as Vostochny, Nakhodka, Vladivostok, Vanino and DeKastri, are the main elements of the rail and marine transport hubs. The Vanino-Kholmsk ferry provides transshipment of more than $90 \%$ of all cargoes arriving on the Island of Sakhalin and back on the rail-sea route ${ }^{5}$.

The main barrier to long-term traffic flows, e.g. on BAM, is practically its entire eastern section, from the Khani station to Komsomolsk-on-Amur and further to Sovetskaya Gavan, including the Kuznetsovsky tunnel on 
the Komsomolsk-on-Amur - Vanino leg. Meanwhile, on the approaches to the Komsomolsk railway junction the freight traffic is projected to grow by 3.3 times by 2015 , and by almost 4.5 times by 2020 . On the approaches to the ports of the Vanino - Sovgavansky hub, the freight traffic is estimated to grow by 3-4 times. And as for the ports of Primorye, the transshipment of all kinds of cargoes there may exceed 91 million tons in 2015, and 100 million tons by $2020^{5}$, which would additionally require, as noted above, a radical reconstruction of the eastern part of the Trans-Siberian Railway and Baikal-Amur Mainline.

Despite the undeniable importance and high importance of the objectives to develop the seaports and railway junctions, railway mainlines and sea transport of the Far East and their infrastructure, the most critical issue for the development prospects of the entire region and sea transport, after all, in our opinion, is the formation and development of the cargo base. This, in our opinion, is not only the basis for the development of all transport modes, present in the region, but also the territory and population living here. Thus, this problem, in addition to the undoubtedly very important, very significant economic component, has a very strong political, social and geo-strategic (global) aspect that, in fact, determines the prospects for the presence (or absence) of Russia in today's Pacific Russia.

\section{Cargo Transit from Northeast China}

To a large extent, this aspect is associated with our closest neighbor, China, more precisely, with its north-eastern provinces of Heilongjiang, Jilin and Liaoning. What can be said in this regard?

First, let us provide some background. In 2008, the gross regional product (GRP) of Northeast China, which includes the province, amounted to about 417.8 billion US dollars, or nearly $9.4 \%$ of the GRP of China ( $8.5 \%$ in 2007). To compare, we can note, for example, that in 2008 the GRP of Primorsky Krai totaled only about 12 billion US dollars, or less than $0.9 \%$ of the GRP of Russia (however, in 2013 the GRP of Primorsky Krai increased to 18.3 billion rubles (about $1.1 \%$ ) (calculated by: ${ }^{9,11}$ ). The growth rate of the gross regional product of Jilin Province (1st quarter 2008) amounted to $16.5 \%$, and Heilongjiang-to $11.4 \%$. It is important to note that in the same 2008, the export volume of the three northeastern provinces of China (Liaoning, Heilongjiang and Jilin) totaled 63.4 billion US dollars, and the import-45.2 billion US dollars. The share of these provinces in the total volume of China's foreign trade amounted to about $4,5 \%{ }^{22}$.

In 2012, i.e. about five years later, the Northeast region of China showed a rather high growth of economic development, higher than the national average. The growth of the Gross Regional Product (GRP) totaled 505.32 billion RMB and (according to preliminary data) amounted to 5,043.07 billion RMB, or about 826 billion US dollars ${ }^{23}$. This is the basis of the cargo base not only for the ports of China, but also, hopefully, for the Russian ports of the south of the Far East. It is noteworthy that, unlike other provinces of China, during the last three to five years, there is a tendency of accelerated development of the north-eastern territories of China. For example, the share of the GRP of Northeast China in China's GDP has grown over the past three years from 9.32 to $9.71 \%$ (by $0.39 \%)$. The highest rate of the economic growth from 2007 to 2012 was demonstrated by Jilin Province: In 2012, the increase of its gross regional product amounted to $12.0 \%$, whereas in Heilongjiang Province it reached 10.0\%, and in Liaoning Province-only 9.5\%. On the Northeast China's average, the GRP growth in 2012 amounted to $10.5 \%$ (the GDP growth of China in the same period was 7.8\%). Jilin Province is the only area of Northeast China, which increased its share in China's GDP as compared to 1978 (from $2.24 \%$ in 1978 to $2.29 \%$ in 2012). However, Liaoning Province still remains the most developed province in the region; the volume of its economy is very close to 2.5 trillion RMB (about 410 billion US dollars), which is more than twice the value of Jilin Province and 1.81 times the value of Heilongjiang Province. In terms of the GDP per capita, the leader is Liaoning Province (56,547 RMB, or 9,270 US dollars); it is followed by Jilin Province $(43,412 \mathrm{RMB})$, and the last in the top three is Heilongjiang Province (35,711 RMB). On the average, the per capita GRP of Northeast China in 2012 totaled 45,223 RMB, or about USD 7,413 ${ }^{23}$.

The largest and closest to Russia province of the PRC is Heilongjiang, located in Northeast China. It is a region of China, which is larger than the Republic of Korea, or North Korea, as well as Japan, and is the sixth largest in the country. In 2011, the GDP of Heilongiang Province reached approximately 198.5 billion US dollars and grew 
up on the previous year by $12.2 \%$. This increment was by $3 \%$ higher than the national average ${ }^{24}$. The province holds, perhaps, the most important position for the prospects of development of the southern transport corridor between Russia and China, and focuses on the seaports of Primorsky Krai.

On April 24, 2009, the seventh session of the 10th Heilongiiang CPC Provincial Committee considered and adopted the "Plan of Trade and Economic Area of Development of Northeast Asia in Heilongjiang Province." According to the plan, in particular by 2015 it is scheduled to develop the border areas in the province, construct an international transport and logistics network in the nodal points of central cities and border crossings, connect the internal production base to the overseas market. To perform these tasks, 25 open border transitions, 11 water passenger lines, 10 bus passenger lines (including ice routes), 2 passenger rail routes, 7 regular and 18 charter air passenger lines connecting Heilongjiang Province with Russia, Japan, South Korea and Hong Kong, were established. Previously, the time of transportation of goods from Heilongjiang Province to Japan and South Korea through the ports of Dalian and Tianjin equaled to 13-14 days (excluding domestic transportation). After the land-sea transport route was opened, the delivery of goods from Suifenhe to Vladivostok reduced to one day maximum, and to Japan-about 4-5 days. This transport corridor allowed implementing three types of transit transport routes: Firstly, the transit route "China - Russia - third countries", by which goods are transported from Heilongjiang Province through the ports of the Russian Far East to Korea, Japan and North America. Secondly, the transit route "China - Russia - China", by which goods are sent from Heilongjiang Province to southern coastal cities of China through Russia. Thirdly, the transport corridor "third countries - China - Russia" that is being formed currently, so that goods from other countries will be transported through the ports of the Russian Far East, then through Suifenhe or Dunin, then through the territory of China to Russian Siberia. As a result, Heilongjiang Province can become the distributor base and the center of foreign trade in Northeast Asia as well as an economic hub of Northeast Asia ${ }^{24}$.

By the end of 2011, high-speed roads were built in Heilongjiang Province, the length of which amounted to $2767 \mathrm{~km}$, including $150 \mathrm{~km}$ of highway. This marked the beginning of the land-sea transportation between
China, Japan, South Korea and Russia. At the same time, 9 airports operate in the province in the cities of Harbin, Jiamusi, Qiqihar, Mudanjiang, Heihe, Yichun, Mohe, Jixi and Daqing. Within the framework of the agreement on strategic cooperation between the government of Heilongjiang Province and the Shenzhen airline, an agreement was signed that in the future, within 5-10 years, the focus would be on the development of a threelevel flight network around Harbin: Firstly, a branched flight network will be created between Harbin and medium-sized and small cities, in particular, Jiamusi, Mudanjiang, Qiqihar, Heihe, Mohe, etc.; secondly, a trunk flight network would be created within Northeast China-between the airports of Heilongjiang, Jilin City and Liaoning; thirdly, an international flight network of Northeast Asia would be created, in particular, between Harbin and major cities in Japan, South Korea and Russia. These three flight networks will comprise a new air channel in Northeast Asia ${ }^{24}$.

At present, one of the most important tasks of Heilongjiang Province is the construction of new import and export industrial and processing zones oriented to Northeast Asia. Today, Heilongjiang Province has about 200 manufacturing companies focused on exports (the average volume of exports of the company is more than 1 million US dollars) and their share in total exports of the entire province is $17.3 \%$. The share of the imported products processing (mainly energy intensive products, agricultural and ancillary industries products) continuously rises: The province currently has 96 enterprises processing imported products and the import of their products has reached 2.42 billion US dollars, having increased by $22 \%$ on the previous year. As a result, the share of these enterprises in total imports of the province amounted to $17 \%$. Over 1.7 thousand companies operate in the industrial zone and the zone of trading with Russia in Harbin, Mudanjiang, Suifenhe and Dunin. A base for the production of energy-intensive products, products of the light and electro-mechanical industry, building materials industry and others has been established there. Thus, in the emerging industrial corridor "Harbin - Daqing - Qiqihar," production, more precisely the industrial cluster focused primarily on the external market, is developing at a fast pace. This cluster primarily includes the mechanical engineering, aerospace and electrical industries, the medical and pharmaceutical industry, petrochemicals, light industry and the industry 
of new construction and industrial materials. Expanding the trade and economic cooperation with the countries and regions of Northeast Asia, the government of Heilongjiang Province has put forward the strategy of "attracting" and "going out of the house." In 2011, enterprises and organizations of Heilongjiang Province invested in production only in Russia 522 million US dollars, or about $66 \%$ of total annual investment of the province. By 2010, at the expense of enterprises and organizations of Heilongjiang Province, 164 wood processing enterprises were established in the Russian Federation with a total capital of USD 1.39 billion. As a result, in 2011 the total volume of trade in Heilongjiang Province reached 38.5 billion US dollars, and compared with the previous year increased by $50.9 \%$ (against the 28.5\%-increment in the entire PRC on the average). That same year, the total volume of trade between Heilongjiang Province and countries of Northeast Asia reached 20.97 billion USD, or $54.5 \%$ of the total volume of imports and exports of the entire province. The main driving force behind the growth of foreign trade across the province was the trade with Russia. In 2011, the volume of trade of Heilongjiang Province with Russia amounted to USD 18.99 billion, or 1.5 times the volume of 2010 . The exports of the province amounted to USD 4.35 billion $(+1.5 \%$ compared to the previous year), or $24.7 \%$ of the exports of Heilongjiang Province to the Russian Federation, and $11.1 \%$ of the total exports of China to Russia. The imports amounted to USD 14.64 billion (3.6 times the value of the previous year), or $70.7 \%$ of the imports from Russia to Heilongjiang Province, and $36.2 \%$ of the total China's imports from Russia ${ }^{24}$.

In accordance with the "Joint Statement of the Russian Federation and the People's Republic of China on AllRound Deepening of the Russian-Chinese Partnership and Strategic Cooperation" dated September 28, 2010, the state bodies and business circles of the two countries were tasked based on their national strategies of modernization and economic development to improve the structure, organize and change the growth model of bilateral cooperation and trade in order to implement the signed between the two countries "Program of Cooperation between the Regions of the Far East and Eastern Siberia of the Russian Federation and the North-East of the People's Republic of China (2009-2018 years)," according to which the parties would fully promote the construction of infrastructure facilities and other major projects of regional cooperation to fully support cooperation between the regions of the two countries using agreed bilateral mechanisms ${ }^{24,25}$. Particular attention in this program has been paid to the investment cooperation in the field of mechanical engineering, telecommunications, banking, insurance, innovation and applied research, the chemical, timber and mining industries, inter-regional cooperation, as well as to the start of construction of the Russian-Chinese gas pipeline, promoting the integrated development of coal deposits, including the development of railways and ports ${ }^{25}$.

What conclusion can be drawn from the above analysis of economic development of Northeast China in the context of the strengthening economic cooperation between Russia and China, including in the part that concerns the prospects of development of the seaports of Primorye and their cargo base?

In our opinion, the main conclusion to be drawn from the material presented above is that Primorye and the entire Far East need a port that would be as close as possible to the border with China and would be linked with China with a transport corridor primarily going to Northeast China. And it must be a new port by its customs and tax regimes and by business organization; a port that would really attract not only Russian, but also foreign investors and carriers. As we have already mentioned, in our opinion we are not talking about copying an Asian port that has a large cargo or container turnover. We believe such a goal is not achievable in the near foreseeable future, and it is hardly possible despite the potential, theoretical possibility ${ }^{26}$. The port must address in the first place, apparently, other tasks, especially the tasks of transit handling of Chinese and Russian cargoes. There is a cargo base for it. However, this is not a Russian, but mostly Chinese base. Neither has Russia sufficient tonnage for the merchant fleet yet. Hence, the important and difficult tasks that we have to solve:

- Firstly, to create conditions for the establishment and development of national Russian shipping companies, to set an attractive tax and financial regime to ensure the impossibility of vessels' leave "under a foreign flag," and to develop the port infrastructure;

- Secondly, to support the transnationalization of Russian transport-logistics and freight forwarding companies, and to encourage the development of the operation of world-class transport-logistics providers in Primorsky Krai; 
- Third, to improve the level of work coordination and the development of transport hubs of Primorsky Krai and Khabarovsk Krai, and to form on this basis an integrated macro-regional transport system through the development of multimodal cross-border transport schemes, primarily by directing the transit of goods from Northeast China through the ports of Primorsky Krai.

\section{The Free Port of Vladivostok and Territories of Priority Development}

In solving these problems, the role exclusive by its functional purpose and scope belongs to the Free Port of Vladivostok (FPV) being established currently in Primorye.

So what is the role and the capacity of the transport and logistics system that is currently being created in Primorsky Krai, which includes (as one of the base, reference elements) the ports of the southern zone of the Far East (especially of Primorsky Krai) in the formation and implementation of the new direction of development of the south of the Far East and, above all, Primorye, the concept of the Free Port of Vladivostok, which in recent months has become a key term in the projects and plans for the development of the Russian Far East? In turn, the reverse question is quite logical: How and in what direction will the establishment of the Free Port of Vladivostok influence on the development of the transport and logistics system of the region and the entire Far East?

We are about to try to answer these questions or, at least, to outline the direction of finding answers to them.

The first of many questions comes to mind immediately: Is the city and port of Vladivostok ready to an increase in the cargo traffic and a change in the customs regime? After all, not only specialists but even residents know firsthand currently that the city does not have an appropriate port infrastructure. In particular, the railway capacity is not sufficient, and transportation of cargoes (e.g., 20-40-foot containers) by road now causes serious obstacles for the normal traffic in the administrative center of the region. Quays of "Commercial Port of Vladivostok" and other stevedoring companies are not able to handle heavy modern vessels (for example, those that have a draft of more than 10-12 $\mathrm{m}$ and a deadweight of more than 80100 thousand tons), and the customs performance, to put it mildly, does not fully meet modern requirements for the arrangement of goods movement across the customs border of Russia. But this, i.e., first of all, preferences and simplification of customs procedures and border control, is assumed by the FPV regime, i.e. by the status of a free port ${ }^{7}$.

We need to recall that a free port is nothing but a dedicated area, into which you can carry duty-free goods, and which encourages to open new productions in its territory and process products produced in it. Today, this term is often understood as a certain territory, in which production or transport-logistics facilities, facilities of industrial, transport, social, and other infrastructure are located, and which is, as a rule, a special customs zone or customs territory, in which simplified customs rules are applicable (or customs duties are completely absent), there is uncontrolled transshipment and other special rules of economic regulation set by relevant agreements and government regulations are in effect.

By definition, the customs border of Russia will lie between the territory, on which this regime is applied, and the rest territory. That is, each person or vehicle crossing the border should pass customs control, and all transferred goods will be subject to customs clearance. Hence, it will be necessary to establish customs checkpoints on the exit from the zone (city) and check virtually every car or person leaving the zone, which does not seem practicable. A similar situation already existed in the XIX century in Odessa (from April 16, 1817 to April 19, 1859), when it was a free port, and there constantly arose similar problems with people coming to work in the port from the suburbs of Odessa-they spent several hours in the evenings in a queue at the customs post ${ }^{27}$.

In addition, for the implementation of the Free Port of Vladivostok project in full scale, huge investment will be required, which due to the crisis are not expected in the nearest future. We are talking, of course, above all, about private investment, as the state will hardly provide the required amount in full.

In this connection, there is another important question, to which there is no answer yet: How will the Free Port of Vladivostok in Primorye (and will it at all) interact with the "Territories of Priority Development" (TPDs)? Perhaps, in case of inclusion in the free port zone of a large part of municipalities of the region, the issue of establishing of PDTs in them will become irrelevant (however, it is not happening yet). Or, perhaps it is worth combining these projects into a single one in the future? By the way, the Federal Law "On the Free Port of 
Vladivostok" (Article 4, Para. 2) expressly states that: "The Free Port of Vladivostok does not include areas, in which a special economic zone, or a territorial development zone, or a territory of advanced socio-economic development have been established"'.

At the same time, it seems quite clear that in order to gain a real (and not just the expected one, which in fact is virtual) economic benefit of the Free Port of Vladivostok, serious calculations are required, as well as a certain amount of imports and exports (the cargo base) and forecasts for their further growth, which in modern conditions is quite difficult to do, given the existing market conditions, the current economic relations and international treaties, the volatility of the ruble exchange rate and restrictions on the import of certain goods from certain countries. One could probably say that the establishment of the Free Port of Vladivostok will encourage transit traffic, but now transit goods are not subject to duties and taxes already, and it is not reasonable to rely on a large increase only due to the reducing cost of ship calls, customs and tax privileges. In addition, the question arises again in this context about the capacity of railways.

In general, if we talk about the "Free Port" status for the seaport in particular, we have to admit that the Vladivostok port is the least attractive option. The port capacity is limited to the city itself (its geographical location on the peninsula). Its transport infrastructure is unlikely to be able to cope with a traffic growth and there is little capacity for its expansion. At the same time, projects related to the use of the Russky Island as well as with the construction of the Vladivostok beltway (VKAD) will not solve all problems. In this regard, the most promising and convenient option could be the port of Zarubino that is under construction currently (the project is implemented by the Summa Company) and that is largely focused on transit cargoes. According to the plan, the port must be one of the biggest hubs for traffic flows between China and Japan, China and Korea, Korea and Japan and, potentially, even between the west coast of the US and China. In addition, an additional cargo base for the Trans-Siberian Railway will be formed there. In this regard, we find it relevant to provide a substantive analysis of the project for the construction of a specialized grain terminal in the seaport of Zarubino for 33.5 million tons of grain a year with capital investments of about 55 billion rubles (including VAT, including government funding amounting to 6.1 billion rubles) and a payback period of about 11 years and a specialized container terminal in the Troitsa Bay with the volume of capital investment equal to 43.6 billion rubles and a planned processing capacity of 2.5 million TEU per year (the construction period is 5 years, the discounted payback period at a rate of $8.5 \%$ is 6.5 years).

Talking about the long-term interest in the region's development, it seems most efficient to provide the free port status not only to individual ports, but to the entire coastal territory of the Peter the Great Gulf (and some other territories of the region) in order to make all the ports of Primorsky Krai "free", including Zarubino, Vostochny and Vladivostok. This provision, in particular, is stated in the federal law mentioned above. Article 4, Para. 1 "Territory of the Free Port of Vladivostok" of the document reads: "The Free Port of Vladivostok includes the territories of municipalities of Primorsky Krai: Artemovsky city district, Vladivostok city district, BolshoyKamen city district, Nakhodka city district, Partizansky city district, Spassk-Dalny city district, Ussuriysky city district, Nadezhdinsky city district, Shkotovsky municipal district, Octyabrsky municipal district, Olginsky municipal district, Partizansky municipal district, Pogranichny municipal district, Khasansky municipal district, Khankaysky municipal district, including the territories and water areas of seaports located on the territories of these municipalities"1.

How could potentially such a wide coverage of territories with the Free Port status be helpful? In theory, this could allow to provide not only a preferential customs regime, but also additional services, such as bunkering of foreign vessels, especially since fuel for ships is cheaper in Russia than in other countries of the region. In addition, it will give an opportunity to arrange not only duty-free storage of cargoes, but also their handling, including the handling for further export of products with high added value. However, there are other, equally complex and important issues.

The most important problems that to our opinion need to be addressed when establishing the Free Port of Vladivostok are the creation and incorporation, first of all, in the interests of Russia, of this regional economy subsystem in the existing mechanism of regional production of goods and services and its integration into the international system of labor division and cooperation and commodity flows. The main and most difficult tasks, 
in our opinion, will be to develop organizational and administrative mechanisms (regulations) of the free port (it is clear that just adopting a law is not enough) as a Special Economic Zone (SEZ); to create a financialeconomic and social mechanism of the Free Port of Vladivostok; to elaborate legal rules and regulations to support the free port's operation and protect the interests of investors and residents; to establish and implement not only an attractive tax and customs regime, but also organizational procedures ensuring maximum comfort in the operation of residents and foreign participants; to solve strategic socio-political and humanitarian problems of the Russian Far East and Siberia development with the help of this tool. From our point of view, the establishment and operation of the Free Port of Vladivostok is not just a strategic move of the President and the Government of Russia associated with the imposition of western sanctions, but also an attempt in modern conditions not to be behind main trends and prospects of development of the economies of Northeast and Southeast Asia countries (primarily China, Korea, Japan, Singapore, Vietnam, etc.) and the whole Asia-Pacific Region, gravitating to the entire Eurasian Economic Community.

Talking about the substance and economic nature of the free port, obviously, we must admit that it was one of the first and (understandably) the simplest form of a Free Economic Zone (FEZ), which in this case acts as a basic, fundamental concept, the determining element of which is the term (special) "zone" or "territory."

In today's global economy, especially in recent decades, the integration processes have started to actively develop and resulted in a situation when FEZ have begun to turn from essentially economic systems of the production and distribution type, of international cooperation and division of labor into integrative economic systems. This has led to a situation when the latter have begun to consistently take the shape of international free trade zones, customs unions, common markets and fullyfledged economic unions. The movement of factors of production in such FEZ, as it is well known, is subject to general economic laws: Capital moves where labor is cheaper, the level of technology is higher, costs are lower, etc., i.e., where it can be used more effectively. The result of this exchange was the leveling of the quality and prices of factors of production, first within the free economic zones themselves, and then through the international exchange of goods and services on a scale of the regional and world economy.
At first glance, it seems clear that the main purpose of the free port establishment is to provide in this territory the most favorable conditions for entrepreneurship and other activities to attract investment in the development of the transport infrastructure, to create and develop productions based on new technologies, tourism, as well as to increase the quality of life in Primorsky Krai. However, these objectives do not exhaust the list of goals and objectives, and must be specified (or new ones must be set) as the work on the project continues. However, a question that still requires a clear statement and an appropriate answer, as well as versatile certainty is: What is the Free Port of Vladivostok actually created (or - will be created) for, and what benefits will the state and the business gain? Without a clear and coherent presentation of the question and without a quite correct and clear answer to it, such a situation can occur as described in the famous fable "Elephant the Painter", and as a result we will have a new sad example of the failed FEZ "Nakhodka." Moreover, with the so-called "traditional" (Soviet in the past, and Russian now) approach, the idea of a free port (Porto Franco) is most likely to be a failure. To avoid it, it is necessary to arrange the actions of all stakeholders in such a manner as was demonstrated in the very recent past in Crimea. Unfortunately, in our opinion, neither the region, nor the entire Far East have such a team. Moreover, as we see it, the trouble is that the people who are trying to or are already involved in the implementation of certain project activities have no common understanding of how and what to do and why they should do it. As the ancients said, nil temerenovandum (nothing should be changed in a rush), or, to paraphrase, "let the idea become mature." Without it, we think no work like that should be started at all.

Of course, it is too early to say what the free port in Primorye will be, but we would very much like to hope that this project will not suffer the sad fate of the FEZ "Nakhodka", and the residents of Vladivostok will not associate the "free port" concept only with the name of a well-known restaurant and a nostalgia for the historical past of the city in the famous period of XIX-XX centuries, when the city had the status of a "free port" (by the way, which was positively assessed both by the then government of the Russian Empire and the city's population).

\section{Conclusion}

Summing up the preliminary results of the analysis of the 
problem, in our opinion, the following can be noted ${ }^{28}$.

- Establishment of the "Free Port of Vladivostok" is a promising and prospective project for the formation of a certain geographically extended cluster in the southern and central zone of Primorsky Krai from Nakhodka to the Russia's border with China and North Korea, including the ports of Vladivostok, Zarubino and other settlements (municipalities), which will be focused on the development of the foreign and domestic economic activity of both Primorye and the entire Far East, and the country as a whole.

- The main objective of the Free Port of Vladivostok according to the statements of the country's leadership and the provisions of the well-known federal law, is to provide in this territory the most favorable conditions for entrepreneurship and other activities to attract investment in the development of the transport infrastructure, establish and develop industries based on new technologies, tourism, as well as to improve the quality of life in Primorsky Krai. However, from our perspective, these objectives do not exhaust the list of goals and objectives, and must be specified (or new ones must be set) as the work on the project continues.

- The experience of formation and development of free ports in Russia (Vladivostok in 1860-1909, Odessa, etc.) and abroad (Malaysia, China, Korea, Singapore and other countries) evidences that it is crucial to consider the peculiar features, i.e. specific conditions, of the development of the military-political, economic and social life in the respective region and country and also the strongest subjective factor in order to make the establishment of the Free Port of Vladivostok effective. Here, there is a serious conflict of interests of the federal government, the territory and potential investors, which must be solved by necessary framework (or general) regulations, both in economic and legal field, including (most importantly) the customs regime.

- To our opinion, the Free Port of Vladivostok establishment must essentially take into account the creation of PDTs in the Far East so that they would complement each other, but not interfere with each other. This problem is rather difficult both legally and economically, particularly because it affects the interests of the military and economic security of the territories. A simple solution of the simplification of customs procedures in this context is a necessary but insufficient condition. If we implement this step only, neither the former nor the latter measures will be effective. Hence, the task is to delimit geographi- cally and unite conceptually the Free Port of Vladivostok and the PDTs by legal regulation and probably to complement one with the other. In this regard, we need to critically reflect on the existing foreign and domestic experience of creation and operation of FEZ and continue the theoretical research in this direction.

- Another question to be resolved is: How can the Free Port of Vladivostok develop and what will be its competitive advantages over other ports in this part of the Asia-Pacific Region, particularly over the ports of China, The Korean People's Democratic Republic and Japan. Some of the key issues here are the cargo base, the interaction with the railway, air and road carriers, the attractiveness of transshipment and bunkering of vessels. It is not yet clear how they will be solved. Another question of the same nature is the time required for the solutions development and decision-making. It is not also clear how within such a short time to solve the whole range of issues. The problem is aggravated by the current political and economic situation in the country and the world, including the effect of sanctions imposed against Russia.

- In conclusion, we would like to note that, in our view, the implementation of the "Free Port of Vladivostok" concept requires to mobilize the whole scientific, methodological and practical potential of not only central federal authorities, but also professionals working in Primorye. Haste and futility of decisions that may be taken in the nearest future or have already been taken may compromise the very idea of the Free Port of Vladivostok, which in this case will remain only a "pipe dream." Moreover, there are multiple comments, doubts and even direct allegations (as opposed to a general "mainstream" of the free port establishment) that we are not yet ready for the creation of the Free Port of Vladivostok. Hence the importance of the purely exploratory, theoretical, prospecting and professional work, its openness and availability of necessary information, which does not admit secrecy or a prohibition of exchanging and expressing different points of view.

\section{References}

1. Federal law of the Russian federation on the free port of Vladivostok. dated 13.07.2015 \#212-FZ [in Russian].

2. Prezidentpodpisalzakon № FZ-473 [The President Signed the Law \#473-FZ]._Available from:_http://www.politforums. net/economics/_1426336927.html [in Russian].

3. ProgrammarazvitiiaDalnegoVostokarezkopodorozhalaiotpravlenanadorabotku [The Price of the Program of Devel- 
opment of the Far East Has Sharply Risen and the Program Has Been Sent Back for Revision]. Available from: http:// www.odnako.org/blogs/show_23999/ [in Russian].

4. Avchenko A. Otkrytzakrytyi port Vladivostok [Open the Closed Port of Vladivostok]. 2015; Available from: http:// expert.ru/siberia/2015/06/otkryit-zakryityij-port-vladivostok [in Russian].

5. Vorontsova N. Razvitietransportnoiinfrastruktury globalnaiazadachaDalnevostochnogoregiona [Transport Infrastructure Development - a Global Challenge of the Far Eastern Region]. 2012. Available from: http://dvkapital.ru/ article/detail/4497[in Russian].

6. Kraineva E. Kontseptsiiuporto-frankovoVladivostokeprodumaiut do kontsaianvaria [The Concept of a Free Port in Vladivostok will be Elaborated by the End of January]. 2014. Available from: http://www.kp.ru/online/news/1934970/ [in Russian].

7. Porto-franko Vladivostok: v Primorye ne ponialiPutina [The Free Port of Vladivostok: Primorye did not Understand Putin]. Available from: http://www.regnum.ru/news/ economy/1881560.html [in Russian].

8. KonteinerooborotportovRossii v 2013 g. [Container Turnover of Russian ports in 2013]. Available from: http://www. logistika-prim.ru/press-releases/konteinerooborot-portov-rossii-v-2013-godu [in Russian].

9. Port Gonkong - oborotiperspektivyrazvitiia [Port Hong Kong: Turnover and Development Prospects]. Available from: cargo.ru/analytics/115 [in Russian].

10. Gruzooborot porta Singapurzaianvar'-mai 2015 godavyrosna $0,6 \%$ - do 243,23 mlntonn [The Cargo Turnover of Singapore in January 2015 grew by $0.6 \%$ to 243.23 million tons]. Available from: portnews.ru/news/201419 [in Russian].

11. Gruzooborot porta Singapur v ianvare-maevyrosna $6,3 \%$ [The Cargo Turnover of Port Singapore in January-May Grew by $6.3 \%$ ]. Available from: http://asiareport.ru/index. php/news/5507-gruzooborot-porta-singapur-v-yanvare-mae -vyros-na-63-.html [in Russian].

12. Gruzooborot porta Singapur v 2014 goduvyrosna 3.5\% [The Cargo Turnover of Port Singapore in January-May grew by 3.5\%]. Available from: http://infranews.ru/novosti/statistic/40602-gruzooborot-porta-singapur-v-2014-godu- vyros-na-35/ [in Russian].

13. Spisokportovpogruzooborotu [List of Ports by Turnover]. Available from: https://ru.wikipedia.org/wiki/ ... [in Russian].

14. Port Shankhai [Port Shanghai]. Available from: http:// sapsan-logistics.ru/shanhay [in Russian].

15. Gruzooborot porta Singapurza 2011 god vyrosna 5,3\% - do $530,48 \mathrm{mln}$ ton [The Cargo Turnover of Port Singapore in 2011 grew by $5.3 \%$ to 530.48 million tons]. Available from: http://tks.ru/logistics/2012/01/16/0002 [in Russian].

16. Konteinerooborot porta Gonkong (Kitai) zaHanvar-mart 2015 godasnizilsiana 8,1\% - do 4,88 mln TEUs [The Container Turnover of Port Hong Kong (China) in JanuaryMarch 2015 Reduced by $8.1 \%$ - to 4.88 Million TEUs]. Avail- able from: http://www.tks.ru/logistics/2015/04/16/0001 [in Russian].

17. Port Shankhai v ianvaresokratilgruzooborotna 3\% [Port Shanghai Reduced Cargo Turnover by $3 \%$ in January]. Available from: http://www.tks.ru/logistics/2012/02/07/0003 [in Russian].

18. TransportnaiasostavliaiushchaiaburnorazvivaiushcheisiaekonomikiKitaya [The Transport Component of the Rapidly Developing Economy of China]. Available from: http:// www.pppinrussia.ru/main/novosti/news/closeup/1808 [in Russian].

19. The Development Strategy of Seaport Infrastructure of the Russian Federation until 2030 (Draft). Available from: http://www.rosmorport.ru/ seastrategy.html [in Russian].

20. ItogovaiarezoliutsiiaVtoroiMezhdunarodnoikonferentsii «BudushcheeRossiiskikhPortov» i 10-i iubileinoitransportnoivystavki «Transtek-2010» [The Final Resolution of the Second International Conference The Future of Russian Ports and the 10th Transport Exhibition Transtec-2010, Russia, Saint-Petersburg]. Lenexpo, 2010 Oct 5-7. Available from: http://www.transtec.transtec-neva.ru/files/File/ Doc/ rezolutionTT2010.doc [in Russian].

21. On the main outcomes of the maritime and inland waterway transport operation in 2011, the targets for 2012 and for the medium term up to 2014. Informational and analytical materials to the enlarged meeting of the Board of the Federal Agency of Maritime and River Transport on 16.03.2012. Available from: http://www.korabel.ru/filemanager/DOCS/0/0/4.doc [in Russian].

22. Izotov DA. Severo-vostokKitaia v usloviiakhmirovogokrizisa [Northeast China during the global crisis]. Ekonomikaregiona [The Region's Economy]. 2010; 4:230-31 [in Russian].

23. Stavrov IV. Osnovnyerezultatysotsialno-ekonomicheskogorazvitiiaSevero-VostochnogoKitaia v 2012 g. [The Main Results of the Socio-Economic Development of Northeast China in 2012]. Oikumena [Oecumene]. 2013; 2:137-48 [in Russian].

24. Chzhun S. Problemystroitelstvatorgovo-ekonomicheskoizonyosvoeniiasevero-vostochnoiAziiprovintsieiKheiluntszian [The Problems of Building a Trade and Economic Zone and Development of Northeast Asia by Heilongjiang Province]. VestnikKhGAEP [Herald of the Khabarovsk State Academy of Economics and Law]. 2012; 6(62):67-74 [in Russian].

25. SovmestnoezaiavlenieRossiiskoiFederatsiiiKitaiskoiNarodnoiRespubliki o vsestoronnemuglubleniirossiisko-kitaiskikhotnosheniipartnerstvaistrategicheskogovzaimodeistviia [Joint Statement of the Russian Federation and the People's Republic of China on All-Round Deepening of the Russian-Chinese Partnership and Strategic Cooperation]. Available from: http://ru.china-embassy.org/rus/zgxw/ t757139.htm [in Russian].

26. Zubov VM. Trillion dliaPrimoryiailikakRossii ne poteriatDalniyVostok [A Trillion for Primorye or how Russia can Avoid Losing the Russian Far East]. 2015. Available from: 
http://daily.rbc.ru/opinions/economics/28/04/2015/553e23 8a9a794718eaf89273 [in Russian].

27. Levitskaia N. Status porto-franko. Prikakikhobstoiatelstvakh Odessa lishilas ego? [The Status of a Free Port. Under what circumstances did Odessa lose it?]. Available from: http://www.bolshoyvopros.ru/questions/804101-status-porto-franko-pri-kakih-obstojatelstvah-odessa-lishilas-ego.html [in Russian].

28. Fissenko AI, Khamaza EA. Sozdanieporto-frankovoVladivostoke: soderzhanie, usloviia, vozmozhnyeformyrealizatsii [Establishment of a Free Port in Vladivostok: the Content, the Conditions, the Possible Forms of Implementation]. Sovremennyeproblemynaukiiobrazovaniia[Modern Problems of Science and Education]. 2015; 1. Available from:// www.science-education.ru/121-19402 [in Russian].

29. AnalizgruzooborotaportovRossii v 2014 godu: osnovnyeitogi [An Analysis of the Turnover of Russian Ports in 2014: The Main Results]. Available from: http://www.pppinrussia.ru/main/novosti/news/closeup/1808 [in Russian].

30. Decree of the Government of the Russian Federation "The Development Strategy of Maritime Activities of the Russian Federation until 2020" dated 08.12.2010 \#2205-p. Available from: правительство.pф/media/2010/12/17/37697/ file/2205p.doc [in Russian].

31. Fissenko AI. Transport aspects of the development of the cargo base in Southern Zone of Pacific Russia. European Science Review (Vienna). (January-February). 2014; 1234 242.

32. Fissenko AI, Kuleshova EA. Sostoianieiproblemyrazvitiiamorskikhportoviformirovaniiaikhgruzovoibazy $\mathrm{v}$ iuzhnoi zone DalnegoVostokaRossii [Condition and Problems of
Development of Sea Ports and their Cargo Base Formation in the Southern Zone of the Far East of Russia]. Sovremennyeproblemynaukiiobrazovaniia [Modern Problems of Science and Education]. (January-February). 2013; 6. Available from: www.science-education.ru/113-11010 [in Russian].

33. Gruzooborot porta Singapurza 2013 godavyrosna $4 \%$ [The Cargo Turnover of Port Singapore in 2013 grew by $4 \%]$. Available from: http://ati.su/Media/News.aspx? $\mathrm{ID}=31038$ \&HeadingID $=1$ [in Russian].

34. Kursydollara SShA (USD) ievro (EUR) za 2008 god [Rates of US Dollar (USD) and Euro (EUR) in 2008]. Available from: http://afga.ru/?p=1197 [in Russian].

35. Port Gonkong - oborotiperspektivyrazvitiia [The Port of Hong Kong - the Turnover and Prospects]. Available from: cargo.ru/analytics/115 [in Russian].

36. SpisoksubyektovRossiiskoiFederatsiipo VRP [List of Federal Subjects of Russia by GRP]. Available from: https:// ru.wikipedia.org/wiki/Список_субъектов_Российской_ Федерации_по_ВРП [in Russian].

37. TransportnaiastrategiiaRossiiskoiFederatsiina period do 2030 goda [The Transport Strategy of the Russian Federation for the Period until 2030]. Available from:http:// rosavtodor.ru/information/Osnovnye_dokumenty/transportnaya_strategiya_rf_na_period_do_2030_goda.html [in Russian].

38. Prezidentpodpisalzakon $« \mathrm{O}$ svobodnomporte Vladivostok» [The President Signed the Law "On the Free Port of Vladivostok"]. Available from: http://primorsky.ru/news/ main/91161/ [in Russian]. 